\title{
From Robespierre to Napoleon: A Mythology of Enlightenment and Bourgeois Utopia
}

\author{
Dawei Bao \\ School of Humanities, Zhejiang University, Hangzhou 310000, China \\ davidbhzxs@126.com
}

Keywords: French Revolution; Ownership; Capital; Justice

\begin{abstract}
The transformations in the French revolution left numerous topics and historical materials for the research about political philosophy, especially for the research about the association between enlightenment and the political ideals in the revolution. The institutional design in the French revolution based on the concepts of democracy and liberty, though underwent the process of populist practice guided by M.Robespierre, still was concluded by Napoleon's dictatorship and legal order. The petit-bourgeois or sans-culottes once expected the egalitarian democracy adopted by the Jacobins and the Committee of Public Safety, finally still were limited by the sever social and economic crisis. While Napoleon's autocracy not only realized the vision of a legal order of rights, but also was taken by the bourgeois as the regime for modern civilization. Napoleon's empire centralized the political power for an effective state machine that can guarantee the safety of private property and capital, which also means the oppression upon the working class inevitably was intensified simultaneously. The triumph of Napoleon and the capitalist supported him, not only ended the political practice of enlightenment concepts, but also ended the radical punishment on corruption. The thesis of rescuing the revolution by moralizing the whole society finally became a petit-bourgeois utopia that never has been accomplished in the capitalist political practice.
\end{abstract}

\section{Introduction}

As the "first half" of the French revolution, the radical political experiment led by the Jacobins and Maximilien Robespierre finally came to an end in the Thermidor reaction. Along with the social and economic crisis that the revolutionary government failed to control, the initial political ideal and philosophical concept have been cooled down by the severe realities. The legal order based on the acknowledgment of private ownership was soon built in the "second half" of the revolution, through the state machine maintained by Napoleon's autocracy. From the revolutionary enthusiasm of petit-bourgeoise to the legal construction of capitalists, the evolution of French revolution has lastingly provided complex or even contradict lessons for contemporary political philosophy. Not only because the revolution successfully disintegrated the feudalist constitution, but also because the dramatic end of the revolution had it performed the tension between political liberation and the economic basis. Though death and fade, the populist and radical democratic plan led by Robespierre and the Jacobins still reveal the importance of the objective conditions for liberty and democracy that decided by the economic relations. As György Lukács’s said: “liberty and equality are not idealist structures, but decided by the social and economic conditions. The actual confirm about liberty and equality made by the French revolution signifies a giant progress in human society.” (Lukács, 2015, 11)

\section{The Crisis in Revolution: the Speculation of Big-Bourgeoise and the Resistance of the Populace}

Given the title of "the Incorruptible”, Robespierre has been long criticized as “utopian”, “agitator” or even "tyrant", which may conceal the actual relations between Robespierre and the historical 
situation during the revolution. The reason and rationality in the political economic program advocated by Robespierre and the Jacobins also has long been omitted under the infamy of "moral utopia" or "terrorism". In fact, before turning to radical violent measures, the initial political idea of Robespierre is even more pragmatic and benevolent than the Girondists, who are obsessed by the patriotic war. Robespierre once was mocked by the deputies in the National Convention, because he insisted the abolition of death penalty. [] He once also kept a neutral and prudent position in the revolutionary enthusiasm of atheism. [] After being elected as a deputy in the convention for the third estate, Robespierre has long been considered as a pragmatic democrat and an egalitarian. In order to be a rousseauist, he tried to avoid the emotions and enthusiasm provoked by the doctrinaires and focus on the interest of the populace by reason and morality. In addition, experienced the turbulence in 1789, the populace, especially the petit-bourgeoise class was equipped by the reasonable judgement. They were not the mobs that can be easily instigated towards Lafayette's cannon on the Champ-de-Mars. Under the unstable material conditions, what the Jacobins provided for the petit-bourgeoise was a project to gain food and equality. Though facing thorny obstacles, the price control order, the land-redistributive order (Ventôse Decrees) and the general election without property limitation, indeed gave the petit-bourgeoise, even the working class and peasants the hope of liberty and equality.

The populist democracy promoted by Robespierre and his supporters intended to correct the parliamentary democracy, which called for the suppression above the convention and the establishment of the organization that can express the will of the normal people (Lukács, 2015, 16). While in fact, the sans-culottes or proletariats haven't been given the right to enter the convention as deputies. The bourgeoisie on the other hand, have already seized the power in the convention, they firmly stood for the interests of the dominators in Paris or the provinces and refused to hand over their right to the populace. Compared with the royalists and old aristocracy who stubbornly tried to provoke armed riots by inciting the conflicts in rural area or collaborating with foreign armies, the way bourgeois deputies to tackle with the revolutionary populace was more effective and safe. Since they not only dominated the food supply, transportation and currency in the city, but also the major land-ownership in the whole country. There were enough economic and financial measures the bourgeois could take to cool down the consistent revolution. In a short time, the angry sans-culottes, who tried to practice radical democracy by assaulting the convention, were seemed to be defeated and crumbled by poverty, hunger, temptation and bribe. However, Robespierre stood out and became a strong representative for the populace. He successfully persuade the Jacobin Club to follow his ideal, which needs to suspend the revolution from transforming to a capitalist kingdom. There is an obvious paradox within Robespierre's political ideal, in which, he tried to keep a rational development associated with capitalist private ownership and democratic constitution, on the other hand, he tried to realize his rousseauist ethical project, which encouraged him to stay detesting towards any form of privilege and inequality (Feher,2014,65). When the major conflict switched from the french citizens and royal family to the populace and rich bourgeois, the weapon to kill liberty was changing from the canon of the King to the hunger imposed by the rich bourgeois. The new crisis and conflicts in the revolution were finally concluded by Robespierre and the Jacobins-save the revolution.

Why the revolution had to be rescued? Charles Tilly sees the main reason is the lack of motivation to continue the revolution. Especially the bourgeois, their attempt of settling old scores with feudalism was realized in the first two years of the revolution, afterwards, their motivation and fever to continue revolution as a purely political action soon faded. Moreover, the war with European powers also assumed up the material ability of France and French people. And in some area, where the political foundation was quite fragile for the new regime, the local representatives were fell into temporary civil wars and riots, which made it almost impossible to mobilize or guide the local people, especially the local peasants (Tilly, 2012, 138).Though Tilly's analysis about the political courses for the crisis is persuasive, the direct threat to the revolution rooted in economic issue, the widely and merciless exploitation on the whole society from the dominant bourgeois, who became the new and legal superiority and nobility through the liberated civil society and market. But the initial aim of the revolution started in 1789 was to set off the construction of a new society, where the inequality and 
slavery shall be eliminated by the democratic constitution. The old nobles' superiority and privilege that originated from the feudalist or natural reason were negated by the revolution in 1789, while the new nobles or bourgeois caused the new contents for the object of the revolution. Based on the sponsor of the foreign nobles, the big-bourgeois not only made fortune from the war and currency turbulence, but also tried to intensify public discontent towards the revolution itself by hunger and rumor (Lefebvre, 1985, 65). Therefore, since the February of 1793, the economic blockade imposed by the foreign factors as well as domestic factors aggravated the economic situation and people's life. The execution of Louis X VI and the claim of war against the whole Europe caused drastic devaluation of assignat and public panic of bankruptcy. The conviction given by the Jacobins clearly towards the foreign bankers, which was true partly, the banks in Amsterdam, London and Hamburg worked hand in glove with the bankers in Paris. However, there were also many French bourgeois took advantage of the crisis by stipulating assignat, selling currency and hoarding food (Lefebvre, 2010, 340).

In the city, food shortage and currency turbulence bred an angry and organized social class named menu people (menu peuple). Actually it was not a typical class. The social identities of the people clarified as menu people were multiple. The petit-bourgeois, including shopkeeper, craftsmen, small traders, or even skilled workers (Skocpol, 2015, 229). These people, called by Turgot and Quesnay as "non-producing class", were extremely vulnerable in the liberated market in the late 18th century. Before 1789, the menu people attributed mass poverty and hunger to the inability and corrupted King and his nobles. While the revolution did not release the shortage of food and inflation, and even aggravated the crucial situation. The menu people soon switched their anger towards the rich and privileged class under the new constitution. When they witnessed even Mirabeau-the saint of the revolution, the deputy of convention and the people, before being tortured to death by his licentious life and syphilis, he was still on the run for the rich bourgeois who wanted to be permitted to run a mine privately. It is no wonder the menu people gave up the hope of eliminating hunger and privilege on the expectation on the National Convention and turned to the Jacobins. Some menu people with political initiative thus became sans-culottes, who were famous for their promotion of radical republic principles and equality. In rural, forced conscription finally triggered the anger accumulated within the peasants, which evaluated to the most serious armed uprising in the country. While the Girondist with the support from arms merchant, still willing to expand the the fever of patriotic war through their demosthenic encouragement. Finally, the peasants in Vendean, commenced their first fierce rebellion in the August of 1793, not to save the old regime or King, or even not to express their anger towards the sectarian division created by the Jacobins, but to express their declaration distinctly - they refused to fight in the war for the the revolution and new regime (Lefebvre, 2010, 345).

After the supreme power of King - the sign of Leviathan in old regime-was abolished, French people found themselves trapped into the war against all. F. Hayek's inference, "the war state that all against all” depicted by Hobbes is a nonsense (Hayek, 2000, 8) —because in the state (e.g.free market) where there's nobody to distribute, there's no distributive justice (Hayek, 2000, 179). This surely demonstrates the basic understanding about "war" and "distribute" as a liberalist, which was proved by the turmoil in French revolution negatively. The big-bourgeois certainly also want to reconstruct peace, the peace that under the precondition of eliminating all the possible political forces to distribute, which used to be held by the King and nobles and now was held by the egalitarians. If all the distributions of food and wealth were given back to the free market dominated by the jungle law, who owns most capital and land can be the invisible distributor legally and safely. The economic situation didn't fulfill the promises the bourgeois made before 1789, as what Sieyes claimed in his book. The revolutionists divided into two parts, some considered themselves as authentic revolutionists, and named the others as old revolutionists or even anti-revolution, including Girondists and Feuillants. The old revolutionists were satisfied with the current constitution and refused to adopt the populist democracy. Under the influence of public opinion and money, the National Convention even tried to suppress the voice from the bottom. While the bankers and other 
bit-bourgeois kept "fanning the flames" by hiring the journalists (Lefebvre, 2010, 362). Moreover, the Jacobins and Montagnard also were divided by the severe social crisis. Danton and his supporters were also tired of the revolutionary politics and tried to settle down a stable ruling by the bourgeois. The political unite appealed by Danton, though attracted many intellectuals and deputies, still was considered unprincipled by Robespierre (Lefebvre, 2010, 342).

In the May of 1793, Robespierre indignantly pointed out: "our attention on the counter revolutionary activities shall not be distracted by the insignificant commodities." He tried to classify the deed of corner the market into the range of counter revolution. He also attacked on the formalist liberty claimed by the liberalists, which he thought was purely a slavery on the populace and a destruction on the revolution. He reaffirmed in Rousseau's tune: "At any time, being responsible for the people is more important than for the voters, we shall lead the voters to go along with the people." (Lefebvre, 2010, 343) In July 10th of 1973, the National Convention finally was reorganized in to Committee of Public Safety (Comite de Salut Public). Soon, the political measures aiming at cracking down speculation were taken by the committee guided by Robespierre and Saint-Just. "The law to punish speculation was passed in July 26th...in August capital outflow was forbidden...the granary to for shortages with surpluses was built in August 9th...the price control on fuel, salt and tobacco was taken in late August." The military suppliers and bankers received a heavy blow after the the victory of Robespierre and Saint-Just in the committee in 1793 (Lefebvre, 2010, 367). However, the salvation of people from economic crisis didn't actually brought by these political measures, capital and land ownership irresistibly gathered into the pockets of the big-bourgeois and their deputies. Bursting the bonds of feudalism, the capitalism after the revolution sharpened the class contradiction in the market economy and civil society. The petit-bourgeois or petty farmers, As Vladimir Lenin commented: "Facing the ever-developing capitalism, any egalitarian economic bodies are incapable of anything." (Lenin, 1988, 78) The attempt of nationalization or egalitarianism of the Jacobins failed to rescue the petit-bourgeois and small farmers in 1793 and 1794.

\section{The Radical Democracy: a Political Project Defeated by Objective Reality}

As a Rousseauist, the living states of the proletariat and rich bourgeois were both considered unnatural by Robespierre, the former is tortured by the sin of deficiency, while the later is corrupted by the sin of excess. Robespierre firmly insist on Rousseau's critique upon the rich and the praise for the ascetic life, as his own living state shows. He believed the state of "neither too rich nor too poor" is the ideal state for a citizen. Because "the rich needs others to serve, while the poor needs others help”, which signifies the danger of becoming slaves (Rousseau, 1962, 125). On this point, Robespierre had similarities with Sismondi- "the best social system is beneficial both to the poor and the rich. What the lawmakers consider is not the equality of conditions, but the happiness under any condition.” (Sismondi, 1983, 23)

Hence, quite understandably Robespierre held a paradoxical attitude towards the big-bourgeois who consistently benefited from the economic disorder and rebellions, which rooted in his understanding about political philosophy and private ownership. On one hand, he truly concluded from the experience in the revolution: "power and fortune generate all the weakness of arrogance, only labour, moderation and honest poverty can become the defender of merits. What the weak expects is justice, and what the weak worships is the enthusiasm generated from integrity." (Robespierre, 1986, 142) On the other hand, he has no intention to construct a new order of ownership based on public property. Though he acknowledged the huge gap between the wealthy and poor was always the origin of tragedy and criminal, he still believed the key to solve the crisis was the moral constraints on individual use of desire. This paradoxical attitude can be seen from his claim towards the big-bourgeois in 1793- "the villainous that only care about gold, I do not want to touch your treasure, no matter how and where you get it." This claim has been understood as the compromise of Robespierre and the Jacobins, because aggravating shortage of food and the anger from the bottom compelled the Committee to cease attacking the free market controlled by the big-bourgeois. Meanwhile, the Jacobins still were searching for the possibilities to build a moralist republic where 
the power belongs to the people and the petit-bourgeois becomes the backbone for the society. Yet, this moralist polis pursued by the Jacobins is not a socialist state, the disparity in wealth caused by nature and contingency still exists, only the privileges and slavery caused by such disparity can be diminished by the law. Eventually, in fact, Robespierre didn't went further than the bourgeois intellectuals at that age. The solution for the slavery and sin in class society reached by Robespierre was "respect". He claimed: "compared with social welfare, the property equality can provide less happiness for citizens. Making people respect the poor is more important than destroying wealth." (Robespierre, 1986, 133)

Therefore, despite the direct execution of the counter revolutionists, the combination of progressive tax and universal suffrage became the constructive way for the Jacobins. Before the Thermidor reaction, socialist public ownership remained a restricted area for Robespierre and Saint-Just, although they showed their distinct despise on the big-bourgeois and the mercy on the exploited populace. The hope to restrict the big-bourgeois from further exploiting the whole society and corrupt the public culture was placed on legislative measures, mainly on the progressive tax and universal suffrage. Robespierre claimed, the essence of progressive tax is "the citizens with insufficient income to keep living shall not pay for social expense, while the other citizens shall progressively bear the public expense by the standard of the amount of private property." (Robespierre, 1986, 135) He also believed it's a holy duty for the rich to help the poor, and the progressive tax is the social way to regulate this duty (Robespierre, 1986, 137). Meanwhile, Robespierre didn't forget to confirm the private ownership as a natural right, he claimed in his modification of Declaration of the Rights of Man and of the Citizen: "ownership is the right of each citizen to use and dominate the property he legally deserves...the right of ownership is as same as the other rights, is restricted by the respect of other citizens' right and duty.” This claim obviously signifies Robespierre's rousseauist ideal of petit-bourgeois utopia.

When Robespierre saw the combination of natural right and social justice in his political construction, he barely noticed such philosophical construction actually stayed in the dimension of formalist rationality, which can be easily denied by the particular desire and freedom of specific owners. He placed his hope of maintaining the organs of authority as a power to protect the public will and social interest on the political participation of populace, which can be seen in his appeal for the universal suffrage without limit of property. He even promoted the most radical democratic project that has ever practiced before, which can only be seen in the theory of the sovereignty of the people in Rousseau's the Social Contract(Du contrat social ou Principes du droit politique). Robespierre appealed to the Committee, people surely can not become judex ordinarius, but they can appoint or depose any public officers by certain regulations (Robespierre, 1986, 148). He also appealed if the social right, natural right or liberty of the people cannot be guaranteed, which declares the fail of the political constitution and power, people can regain their natural right of protecting all rights independently (Robespierre, 1986, 139).

The rousseauist revolutionary government and Robespierre's political expedition finally failed in 1794. In the realities of mass poverty and corruption, Robespierre appealed to the populace to join his expedition of rescuing the republic by saving the revolution:

"The revolutionary government has saved the motherland and now has to avoid all the hidden reefs to save itself. Because the enemies that originally tried to paralyze it, now are trying to draw a conclusion of abandon the revolution by corrupting it.” (Robespierre, 1986, 221-222)

In fact, neither Robespierre and the Jacobins, nor the angry sans-culottes, had the financial and social ability to against the poverty or rumor, from which the big-bourgeois benefited the most as the dominant class. The political investment in public opinion before and after the revolution proved Adams Smith's judgment: "the capitalist surely can make better decision on the issue of investment than the politicians or lawmakers." (Smith, 1972, 199) The Jacobins and sans-culottes, as the representatives for the petit-bourgeois, the people without the capital to against the big-bourgeois, but kept on their journey of conquering the private capital and the weakness of desire. While the big-bourgeois easily accumulated the power to cease the revolution by consistently investing the propaganda that can influence the public opinion, as well as the currency market that can decide the 
lives for all. As Karl Marx said: "the reason why Robespierre, Saint-Just and their Jacobin party finally failed", partly because "they believed the confirmation of modern capitalist society must in the form of human right... at the same time, they tried to cancel the living performance of this society by individuals afterwards.”(Marx, Engels, 2009, 322)

\section{The Dictatorship of Napoleon: A Final Denial of Revolutionary Concept of Justice}

Since the Bastille of 1789 July 14 to the Waterloo of 1815 June 18, the last spark of French revolution was put out by the conservative forces, the revolutionary flag with blue, white and red was replaced by the flag of Bourbon dynasty. Because of the lone time clumsy performance of the Coalition, and the epic or legendary ending of Napoleon Bonaparte's empire, Napoleon's initial opportunism and despotism were eventually ignored or forgiven by the later generations. The bourgeois military empire established by Napoleon, on the other side, was decorated with the French nationalist sentiment and became an abstract legend. Certainly, compared with the Napoleon's empire in the nationalist narration, his efforts to build a modern constitution displayed a concept of justice that is more universal. The bourgeois rights and the military dictatorship to protect these rights, not only catered to the political and economic appeals from the capitalists since 1789 or 1794, but also brutally surpassed the Jacobinism and socialism that might negate these appeals. As Karl Marx's comments in the Holy Family(Die heilige Familie), the revolutionary terrorism carried on by Napoleon was the last fight of the capitalist society born in this revolution. The end of the revolution obviously refuted Robespierre's moralistic thesis: "the revolution will be finished when the kind and pure people obtain happiness.” (Aulard, 1897, 594) In another words, the dominant class of the revolution decided to terminate the revolution under Napoleon's autocratic rule. The main reason for this is Napoleon was the only person who accurately grasped the essence of modern nation-on the premise of a well developing of capitalist society, which including the realization of private interest and the practice of free will, also, Napoleon had the power and will to "protect this premise" (Marx, Engels, 2009, 324). The bourgeois private law laid by the Napoleon Code (Code civil des Français) convicted the revolutionists since 1789 and provided a historical reason for the invasion of French army, which has long been considered as a career to spread liberty and right. In the Code, the state power officially admitted the private attribute of ownership. The ownership of capital and land, though may cause economic turbulence in personal operation, can still be kept as an absolute exclusive right of domain(potestas). The Code provides the necessary protection for the capitalists which the Jacobins tried to infringe for political reason: "Private persons have the free disposition of the property belonging to them, subject to the modifications established by the laws... One may have over property either a right of ownership, or a simple right of enjoyment, or only claims for ground-services.”[]

The first outcome of the capitalist order of justice realized by Napoleon's regime was massive privatization and capitalization. The "inopportune" measures for nationalization and equal share promoted by the Jacobins soon were corrected by the new government. In fact, the revolution from 1789 to 1794 has already removed numerous obstacles in the way of capitalism. Since the downfall of feudalist regime, by taking the state machine, the capitalists or third class rapidly replaced the old mediators between political power and civil society, including land lord, feudal lord, corrupt officials, clergies and local oligarchs. During the economic crisis and food shortage, the bourgeois government, both the moderate and the radical, chose the side "with consumers against producers, with the city people against the peasants." (Lefebvre, 2010, 624) The Jacobins promoted the nationalization of rural land, not for the interest of the peasants, but for the legal reasons to levy the agricultural products massively. Maurice Agulhon believes the revolution made the land owners much more cling to the land. Because the revolution did not trigger the re-distribution of land, but intensified the further division of rural land, which caused a huge amount of peasants living a vulnerable life on separated small land. This is exactly the perfect condition for massive capitalization of rural land, “the small land owners didn't have the ability to provide for themselves, neither can they keep their freedom.” (Solé, 2015, 291) The France that Napoleon firstly ruled, was no longer an ancient nation. 
The way for the development of capitalism from Paris to Marseille has already been paved by the revolution lasting for 10 years (Tilly, 2012, 134).

The second outcome was the growing gap between rich and poor. Before the Thermidor reaction, the most profitable business, including speculating food and currency trade, always meant huge risk of being punished by the revolutionary laws made by the Jacobin rule. While in Napoleon's time, the accumulation of capital in various ways was no longer harnessed by the revolutionary politics. On one hand, some big-bourgeois benefited drastically from the successive wars commenced by Napoleon, the gold from the foreign countries persistently flowed into France (Lefebvre, 1985, 170).

On the other hand, the bankruptcy of small land owners was accelerated by the capitalization of agriculture. Numerous farmers and peasants became a new working class. The history of "agricultural price scissors" caused by the revolution was demonstrated by Paul Lafargue in the Evolution of Property from Savagery to Civilization. He criticizes the "revolutionary legend of 1789" that depicted the revolution as a salvation of peasants. The "revolution" in fact only benefited the large and medium land owners, as well as the capitalist.[]

In Napoleon's empire, the pitiful sight of small farmers and peasant was a sharp contrast with the city bourgeois and financial asset class. The utopian socialist Louis Blanc sighed: "where there is a starved poor with pallor, there will be a frightened rich with pallor.” The free competition of capital after the revolution was somehow a destructive institution for the people, which became the persistent power to bankrupt the petit-bourgeois and farmers (Blanc, 1983, 24).

In the end, along with the surrender from nobles, clergymen(even the Pope), petit-bourgeois and farmers, the third outcome was the oppression on the working class finally became legal and universal. For the first time in the history, the bourgeois can try to resist the working class from revolting, in the authority of the republic and law. This signified the right of bourgeois, which was gained by the revolution as a social movement and originally limited as the basis for democracy, transformed into power. The domination in economic dimension finally won its surplus form, which can be seen from the legal order in Napoleon's empire. The state power began to associated with the economic right, which was mostly dominated and owned by the big-bourgeois. In order to sustain the best economic circumstance for the regime and dictatorship, Napoleon and his supporters spared no effort to create the "perfect conditions" for the capitalist production. In fact, the right of the working class was neglected in the first period of the revolution, even the Jacobins did not classified the working class as the citizen or menu people. Karl Marx pointed: "In the beginning of the revolutionary storm, the French capitalists deprived workers from the right of association." (Marx, 2009, 850) In June 14th 1791, the National Convention passed a law declaring any forms of worker's association were "infringe upon liberty and Declaration of the Rights of Man and of the Citizen". The workers joined the association would be fined 500 livres and deprived one-year citizenship. The capitalist tried to limited the class struggle between the capitalist and worker by such police forces, which was confirmed by the lawmakers claiming standing for the universal interest and liberty of all French people. The laws passed and reconfirmed in the prohibition to continue the slavery upon the poor.These bad laws apparently against the natural right were not negated by the revolutionary government dominated by the Jacobins, who claimed the advocators of people's democracy and the survivor of the revolution. In Napoleon's empire, the big-bourgeois demanded more "freedom of labour", which Napoleon "coincidentally" agreed and respect such "freedom", which finally were written into the laws of the empire. Given more "freedom", the big-bourgeois were permitted to invest the fields that were not open to private in earlier period of the revolution (Bonaparte, 1991, 170), on the other hand, they were armed with more legal measures to oppress the workers. In March 18th 1806, in order to resolve the disputes between capital and labour, the French government set up a specialized committee, but workers and their representatives were not allowed to participate the committee. The perfection of the legal system and state machine realized by Napoleon's dictatorship, became a ladder, by which the capitalism in France rise up to an independent social power. As Georges Lefebvre concludes: "the capitalism continued the control and oppression on the workers, meanwhile, the revival of guild was prevented.” (Lefebvre, 1985, 172) 


\section{Conclusion}

Today, the justice legend about 1789 and Napoleon was continued in the political ideology. The liberalism, has been accepting the liberal part of the revolution and Napoleon's legislative work for free market, and criticizing the authoritarianism of the Jacobins and Napoleon. When Benedetto Croce describes the "French nationalist empire" after the fail of Napoleon- "the genius tyrant", as a nation that can light up the hope and claim for independence and liberty in all nations. Croce somehow omitted the historical facts that liberty, justice or independence were not the thesis for this capitalist revolution in the first place. As a dominant class in civil society, the big-bourgeois or capitalists only saw the prospect of the legalization of private ownership and more freedom to exploit the workers. The concept of liberty or justice was merely an ideological tool to instigate and organize the petit-bourgeois and farmers. As Karl Marx's analysis: "the vacant soul of private interest was never illuminated by the concept of nation, whereas, its presumptuous demands were ordeals to the nation...the private interest was expecting and hoping to transform nation into a measure for itself."(Marx, 2009, 261)

The French revolution reflected a distinct contrast between the big-bourgeois and petit-bourgeois on the thesis of the nation, which was the prominent historical outcome of the revolution and named after republic. For the big-bourgeois, the concept of nation meant people's submission to the order, as well as politics' submission to the free market; for the petit-bourgeois, the concept of nation meant a justice force to keep them free. To the big-bourgeois, justice, liberty and democracy were just like honesty to the nephew of Rameau in Denis Diderot's depiction. They didn't care about the negative comments on them by the enlightenment philosophers(or their students like Robespierre). As long as within the limit of law, they could be honest, only if honesty was good for their interest; they could also be dishonest, only if dishonesty was good for their interest (Diderot, 1981, 249). The big-bourgeois and "nephew of Rameau" successfully refuted Diderot and reflected the weakness of enlightenment and revolutionary ideals. As the nephew of Rameau claimed in Diderot's "record": "after another forty-year misfortune, only the one can smile to the last is the best." (Liu, 2007, 285) Indeed, approximately forty years after the death of Diderot and Rousseau, the French people experienced the revolution from 1789 to Napoleon, during when the big-bourgeois or "nephew of Rameau" performed their political craft of using the concepts of liberty and justice flexibly. They truly became the real masters after the downfall of the King, because they were the social class successfully transformed their rights into power, in another words, they fulfilled Rameau's expectation and became "the ones smile to the last".

Meanwhile, besides the basic principles of civil society and free market admitted by the Code, Napoleon's dictatorship also provided another successful "ruling model" for the dominant class in other European nations. Charles Tilly sees that the regime of Napoleon's empire survived in other places after 1815, since when the whole Europe were going to be ruled by the centralization of authority (Tilly, 2012, 133). Learning from the fail of the Jacobins and the accomplishment of Napoleon, the Junker in Prussia started to associated their political power with the bourgeois, the British conservative parties started to form ally with the financial capitalist. Even today, we still can see the paradoxical and ideological shadow of the French revolution, which has been well performed by the politics of United States, the nation that was once named by Karl Marx as the "perfect modern nation", where the chairs of Senators have been tightly linked with the pockets of the bourgeois in the Wall street. The fact of social exploitation and inequality were covered by the abstract liberty written in the constitution and laws, as the reflection of the will of the people, most of whom actually do not have the right to truly influence the lawmakers and state machine. This paradox initiated from the "negative synthesis" promoted by the justice legend about the French revolution. Within this "negative synthesis", the material production dominated by the capitalist lashes the individual practice, which brought individual into a static entia. However this is also a fragile entia, because the existing individual equals others and stays away from the practice of liberty, which not only consists of the enlightenment philosophy and the utopia for the petit-bourgeois (Badiou, 2009, 22). The practice of living in unalienated world, which is attached with the natural right, shall also be included. 


\section{References}

[1] Lukács, G.1991. The Process of Democratization, NY:State University of New York Press. Feher, F.1988. The Frozen Revolution: An Essay on Jacobinism, Cambridge: Cambridge University Press.

[2] Tilly, C.2012. Coercion, Capital, and European States, AD 990-1992, New Jersey: Wiley-Blackwell, 1990.

[3] Lefebvre, G.1969. Napoleon from 18 Brumaire to Tilsit 1799-1807, translated by J. E. Anderson, NY: Columbia University Press.

[4] Lefebvre, G.1968. La Révolution Française, Paris: Presses Universitaires de France.

[5] Skocpol, T.1979. States and Social Revolutions: A Comparative Analysis of France, Russia and China, Cambridge: Cambridge University Press.

[6] Hayek, F.1988. The Fatal Conceit: The Errors of Socialism, Chicago: The University of Chicago Press.

[7] Lenin, V.1988.Vladimir Lenin Complete, Beijing: People's Publishing House, vol.17.

[8] Rousseau, J.J.1954. Discours sur l'origine ET les fondements de l'inégalité parmi les hommes. Paris: J.L.Lecercle Agrégé de l;Université.

[9] Sismondi, J.1827. Nouveaux principes d'économie politique, ou de la richesse dans ses rapports avec la population, University of Michigan Library.

[10] Robespierre, M.1986, Revolutionary Legal System and Trial, translated by Zhao Han-yu, Beijing: The Commercial Press.

[11] Smith, A.1982. The Wealth of Nations, London: Penguin Classics

[12] Marx, K. Engels, F.2009. The Holy Family, Marx and Engels Complete, vol.1, Beijing: People's Publishing House.

[13] Aulard, F. A.1897. La Société des Jacobins, vol.5, Paris: Librairie Jouaust.

[14] Solé, J.1988. La Révolution en questions, New Haven: Yale University Press

[15] Blanc, L.1845. Organisation du Travail, University of Michigan Library.

[16] Marx, K.2009. The Capital, Marx and Engels Complete, vol.5, Beijing: People's Publishing House.

[17] Bonaparte, N. 1991.The Selected Works of Napoleon Bonaparte, vol.2, translated by Chen Tai-xian, Beijing: The Commercial Press.

[18] Diderot, D.1981.The Selected Philosophical Works of Denis Diderot, translated by Wang Tian-ji, Beijing: The Commercial Press.

[19] Liu, M.J.2007, History of French Literature, vol.1, being: People's Literature Publishing House. Badiou, A.2009. Pocket Pantheon, Trans by David Macey, London: Verso. 